\title{
Homeobox Protein Hox-C11
}

National Cancer Institute

\section{Source}

National Cancer Institute. Homeobox Protein Hox-C11. NCI Thesaurus. Code C97576.

Homeobox protein Hox-C11 (304 aa, 34 kDa) is encoded by the human HOXC11 gene.

This protein is involved in both transcriptional modulation and endoderm development. 